\title{
On the lists of the patriarchs of Constantinople from 638 to 715.
}

Upon the chronology of the patriarchs of Constantinople down to the year 638 fairly accurate information is to be found in Sokrates, Sozomen, John Malala, the so-called Zachariah of Mytilene, John of Ephesos, the Paschal Chronicle, and other authorities; while from 715 onwards the dates of each patriarch's ordination and death ${ }^{1}$ ) are generally given by Theophanes and his continuators: but for the intervening period we have to depend almost entirely upon the catalogues which give the length of each patriarch's tenure of the see, information which is defective in many ways; for in the first place nothing is more easily corrupted than lists of numbers, in the second place the lists seldom give the number of days, sometimes not the number of months, and in the third place we are left in the dark as to the length of the racancy between each episcopate.

Under these circumstances it seems worth while to attempt with the help of these catalogues and such scanty data as may be obtained from other sources to discover, firstly, the form of the list of patriarchs from which our existing catalogues are derived, and, secondly, the actual chronology upon which this list is founded.')

The catalogues in question are as follows:

1. The years ascribed to each patriarch by Theophanes (circ. 815)

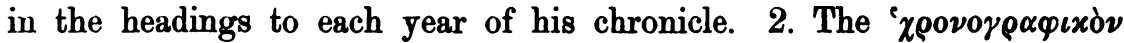

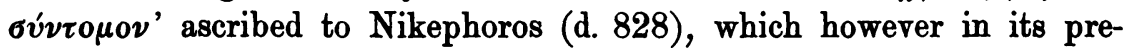
sent shape comes down to the accession of Photius (857), and in one

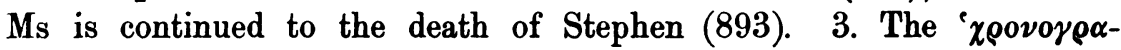

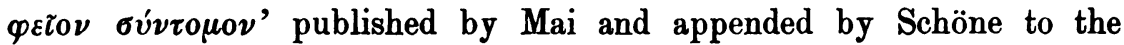
$1^{\text {st }}$ volume of his Eusebius. The list of patriarchs contained in this work comes down to the death of Methodius (846). 4, 5. Two catalogues from Vienna Mss published by Fr. Fischer (De patr. Cpolita-

1) Or other termination of his episcopate.

2) Since writing the above my attention has been called by the editor to the recent work of I. Andreev 'вонстантиноподыcкie патріархи' (Mовcow 1895), which goes over much the same ground as this article, and though by a somewhat different method, arrives at similar results. I have derived a certain number of references from Andreev's work; especiaily with regard to the menologies: these I have incorporated with my article or added in notes. But the substance of the article remains unchanged.

Byzant. Zeitschrift VI 1. 
norum catalogis), of which one extends to the death of Nicolas Chrysoberges (995) with a continuation to that of John Xiphilinos (1075), and the other to the abdication of Kosmas (1081). These two lists . have a common source, which according to Fischer extends to the death of Nicolas Mystikos (925); but it is clear that the notices of Stephen and Tryphon are derived from the same source, and the addition of the months to Nicolas Chrysoberges alone seems to show that the common authority extended as far as the death of that patriarch (995). ${ }^{1}$ ) 6. A catalogue published in the Jus Graeco-Romanum of Leunclavius and reprinted in Banduri's 'Imperium Orientale' tom. 1 p. 171), extending to the patriarchate of Joseph (12671274). As however the last four patriarchs have no number of years assigned to them, it is probable that it originally ended with the death of Manuel Charitopoulos (1255). 7. The catalogue of Nikephoros Xanthopoulos, which extends to the restoration of Athanasius (1303). 8. A catalogue published by Labbe (De Byz. hist. script.

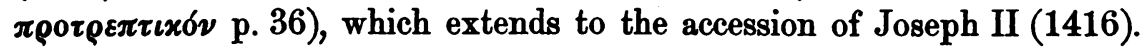
Of two later catalogues, those of Matthew Kigala and Philip the Cyprian, both published by Banduri, it is not necessary to take any account, as they are only bad copies of the Leunclavian Catalogue. Besides these catalogues Zonaras (circ. 1120) mentions the length of several - episcopacies in figures clearly derived from the same original source. ${ }^{2}$ )

Of these catalogues 'Nikephoros' ${ }^{3}$ ), the Vienna lists, Xanthopoulos,

1) The difference in the number of months ascribed to him is probably due to a copyist's error. It is certainly strange that Xanthopoulos and the Leunclavian Catalogue also insert the months in this case.

2) To these must be added two lists. which have come to my notice since the completion of this article. 1. A catalogue published by G. Grosch (De Cod. Coisliniano 120. Jena 1886; see Byz. Zeit. vol. 1 p. 637), which gives years only as far as the first expulsion of Photius (867), followed by a list of names to the second episcopate of Nicolas I (911-925). This list is practically identical with the Labbean Catalogue. 2. A catalogue contained in Brit. Mus. Add. MS 19, 390, noticed by Burckhardt in Byz. Zeit. vol. 5 p. 465, which reaches to the death of Theodotos (821) and is continued in another hand to Polyeuktos (956-970). Burckhardt supposes this to be a MS of 'Nikephoros'; but it does not bear Nikephoros' name and contains many of the variations found in the 'xpovo-

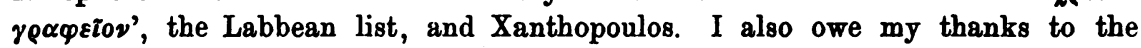
editor for calling my attention to the chronicle in part published by Mercati (Stud. e docum. di Storia e diritto 12 p. 325; noticed in Byz. Zeit. 1 p. 637); but this Constantinople portion, being unpublished, is inaccessible to me. Since however this list reaches to the same point as the Coislinian list, it is probably only another copy of it.

3) I use 'Nikephoros' to express the Catalogue of 857, which is probably only a corrupt epitome of the original work of Nikephoros. The distinction 
and the Leunclavian Catalogue for most of the period covered by this article give the months, and in some instances the days, as well as the years, while the others give years only. The years however are not, at least in Theophanes ${ }^{1}$ ), obtained by simply omitting the months, but are the nearest number of years to the total length of the episcopate ${ }^{2}$ ), thus making it probable that in the list used by Theophanes the months as well as the years were inserted; indeed in the case of the $2^{\text {nd }}$ episcopate of Pyrrhos, which lasted less than 6 months, the months and days are actually given by him. Zonaras also in this instance and in that of Thomas gives the number of months, showing that he also had a similar list before him.

Of these authorities the most trustworthy is Theophanes, since he repeats the number of years each year of the patriarchate, so that the chance of copyists' errors is reduced to a minimum; on the other hand his synchronisms are, as de Boor has shown, practically worthless. ${ }^{3}$ )

The greatest detail is however provided by Xanthopoulos and the $1^{\text {st }}$ Vienna catalogue, which not only tell us which bishops were deposed and what offices each held before his election, as is also done by the Leunclavian and the $2^{\text {nd }}$ Vienna list, and in a shorter form by 'Nikephoros', but also in one instance in this period give the date of ordination and the length of the vacancy - Xanthopoulos alone gives us in one case the date of death. ${ }^{4}$ ) The last-named and the Leunclavian Catalogue also mention the Emperors with whom each patriarch was contemporary; but, as these notices are often wrong, and the Emperors are described by their nicknames ${ }^{5}$ ), they are probably late additions.

established by de Boor between a shorter and a longer recension of 'Nikephoros' need not be here considered, since in both the list of patriarchs comes down to 857, and in the period with which I am dealing the difference is scarcely perceptible; see p. 42 note 5.

1) In the other two lists it seems doubtful whether the compilers followed any consistent system on this point; but they are so carelessly compiled that it is impossible to feel any certainty about it.

2) In the later portion, from Niketas onwards, this is not so: but the reason is plain; here Theophanes mentioned the actual dates of ordination and death in his narrative and was obliged to arrange his headings accordingly.

3) De Boor, Theophanes vol. 2 pp. 464-515.

4) That of Pyrrhos, whose second episcopate seems to have been accidentally omitted by the original of the Vienna lists.

5) There is one instance of a nickname in 'Nikephoros', where under Kalli-

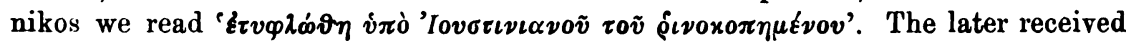
form of this name is however ' 
Further the fact that the dates of ordination and death and the length of the vacancy are given in the same instances in Xanthopoulos and the first Vienna list ${ }^{1}$ ) shows that the original catalogue inserted them only in those instances; and on examining them the reason for this is clear: the two dates mentioned coincided with church festivals, and the vacancy was an exceptionally long one; hence we are justified in assuming that in other cases the vacancy was only of ordinary length. In the earlier portion of the catalogue indeed Xanthopoulos gives us the intervals which followed the two episcopates of Eutychius; and he and the Vienna lists both state that Eutychius was ordained before the funeral of Menas. ${ }^{2}$ ) The Vienna lists also give the year of Menas' ordination, the year of Eutychius' deprivation is given by all the detailed lists, that of the ordination of John the Faster is given by the 2"d Vienna list, and that of his death by Xanthopoulos. There can be little doubt that all these details were comprised in the original; and we may therefore fairly assume that the catalogue down to this point was composed during the episcopate of Cyriac (595-606), the successor of John, and that the portion with which I am now dealing was added later.

Again within this period there is a clear break after Paul ' $\alpha$ ' $\boldsymbol{x}$ ' $\lambda \alpha i x \tilde{\omega} \nu^{\prime}$. Down to this point the months are regularly given, while after this, with one doubtful exception in Xanthopoulos, they are not again found until the episcopate of Niketas, from which point they again occur regularly down to Nikephoros. From this it may be inferred that the section extending from Cyriac to Paul was completed during the episcopate of Paul's successor Kallinikos (694-705). ${ }^{3}$ ) It was not however necessarily or probably written all at one time: each patriarch's notice may well have been written in his own time and that of his successor; but the insertion of the days in some cases and not in others would lead me to conjecture that one portion was added under Peter (655-666), and another in the first episcopate of Theodore $\left.(677-679){ }^{4}\right)$ The succeeding portion from Kallinikos to Nikephoros was then completed during the episcopate of Nikephoros (806-815),

1) The instance of Pyrrhos is not an exception, for, as above stated, his second episcopate has fallen out in the Vienna lists.

2) According to the $2^{\text {nd }}$ Vienna list on the day of his death.

3) I here assume the dates which I shall afterwards try to substantiate for these patriarchs.

4) This is confirmed by the epithet 'bevódogog' applied to Theodore in 'Nikephoros'. In the notice of his second term also Leuncl. and Xanth. call

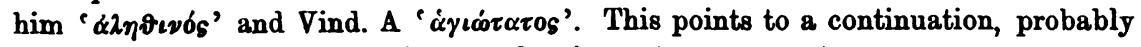
by the same hand, during his second episcopate (686-687). 
and, we can scarcely doubt, by the patriarch himself, the great detail which we find in the $1^{\text {st }}$ Vienna list under the episcopates of Paul, Tarasius, and Nikephoros, being the personal reminiscences of the author. At first sight the difference between this list and the others in these three patriarchates might lead us to suppose a different source to have been used; the others however contain practically nothing that is not found in the $1^{\text {st }}$ Vienna list, and the omission of these contemporary details is natural in later compilers. The correspondence of the instances where the months are given is sufficient proof that the common source did not cease at this point, and the $2^{\text {nd }}$ Vienna list, which is undoubtedly derived from the same source as the first, is here scarcely longer than the others.

Whether Nikephoros is the author of the whole portion from Kallinikos to his own time may however possibly be doubted; the detailed list of previous offices held by each bishop ceases with Niketas, and at the same point begins the mention of the months: hence it is not improbable that the portion from Kallinikos to Niketas was added either during the episcopate of the latter $(766-780)$ or during that of his successor Paul (780-784). ${ }^{1}$ ) This portion, as, if all added at one time, is natural, shows traces of inexactness: thus all the lists agree in giving Germanus 15 years, though from the exact dates in the narrative of Theophanes we know that his episcopate only lasted 14 y. $5 \mathrm{~m}$., a term which in round numbers should have been described as ' 14 years'. The number ' 15 ' was probably obtained by simply deducting the number of the year in which he was inaugurated from that of the year in which he was deposed, a method of reckoning which would not be natural in a contemporary.

All the lists in which months as well as years are given may therefore be traced to an original catalogue composed by Nikephoros during his patriarchate $(806-815)$. The question of the relationship of the lists to one another is however an exceedingly complicated one; it is not at all improbable that some of the compilers drew from more than one source, and we can scarcely expect to arrive at the exact truth upon the matter. Fischer's account, which neglects the lists in which months are not given and derives the detailed Leunclavian Catalogue from the jejune list of 'Nikephoros', is however far from satisfactory; and therefore before attempting to reconstruct the original catalogue it will be necessary to establish a few broad facts relating to the subject without any pretence of exhausting all the possibilities of the case.

1) The list of offices must of course in every case be taken from a strictly contemporary document, since such facts would not be known afterwards. 
I have already shown that the original of the Vienna lists was in all probability composed in the patriarchate of Sisinnius (995-999). ${ }^{1}$ ) On the other hand Fischer has pointed out that the detail bestowed on Nicolas Mystikos and the omission of his rival Euthymius shows the hand of a contemporary; and we may therefore suppose this portion to have been written in the time of Stephen (925-928). The notices of the next two patriarchs however also show more detail than usual, and I should therefore suppose them to have been added, possibly by the same hand, in the episcopate of Theophylact (933-956).

The correspondence between the Leunclavian list and Xanthopoulos ceases apparently with Chariton, and the original may therefore be assigned to the episcopate of Theodosius (1178-1183), though an earlier hand may probably be traced in the epithet ' $\boldsymbol{\theta} \varepsilon 0 \pi \rho \delta \beta \lambda \eta \tau o s$ ' applied to Nicolas Grammatikos (1084-1111), which can hardly proceed from any but a contemporary.

When we come to consider the relationship between this catalogue and the Vienna lists, the question is more difficult: that they run together down to Methodius is clear from the identity of the instances in which months are mentioned; but beyond this point the connexion seems doubtful ${ }^{2}$ ), and there are some remarkable divergences. Moreover the connexion between 'Nikephoros' and the other lists ceases at the same point; for the former and the continuator of 893 continue to give months after Methodius, while the others give years only. Hence it seems to follow that all our detailed lists (except the London one) are derived from a catalogue made during the first episcopate of Ignatius (846-857), which was itself a continuation of the work of Nikephoros.

On the other hand in the period with which $I$ am dealing there are two conspicuous instances, those of the earlier John and of Con-

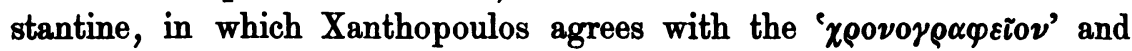
the Labbean Catalogue in a number which is at variance with all the other lists. From this it would seem to follow that besides the source of the Leunclavian catalogue Xanthopoulos also used a corrupt source

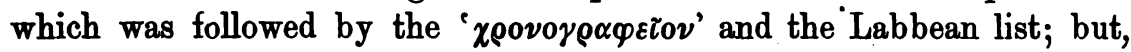

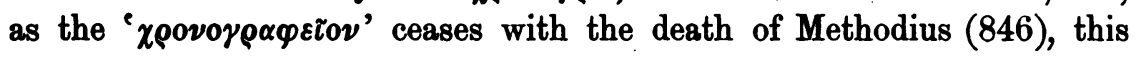
source must have been written before this date. $\left.{ }^{3}\right)$ That this source was not

1) Or at least not earlier than that of Theophylact (933-956).

2) I have already noticed the addition of the months to Nicolas Chrysoberges in both; it may however be remarked that the Leunclavian list adds the months to several patriarchs about this period.

3) As noticed above (p. 34 note 2) the London list seems to be also derived 
of independent origin but was itself derived from Nikephoros may be

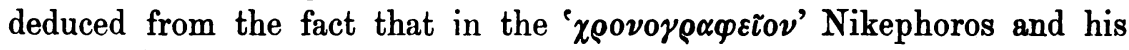
first two successors have no number of years assigned to them. The document was therefore in all probability a brief epitome of Nikephoros without addition or with an addition of names only. ${ }^{1}$ )

For the sake of clearness I subjoin a stemma:

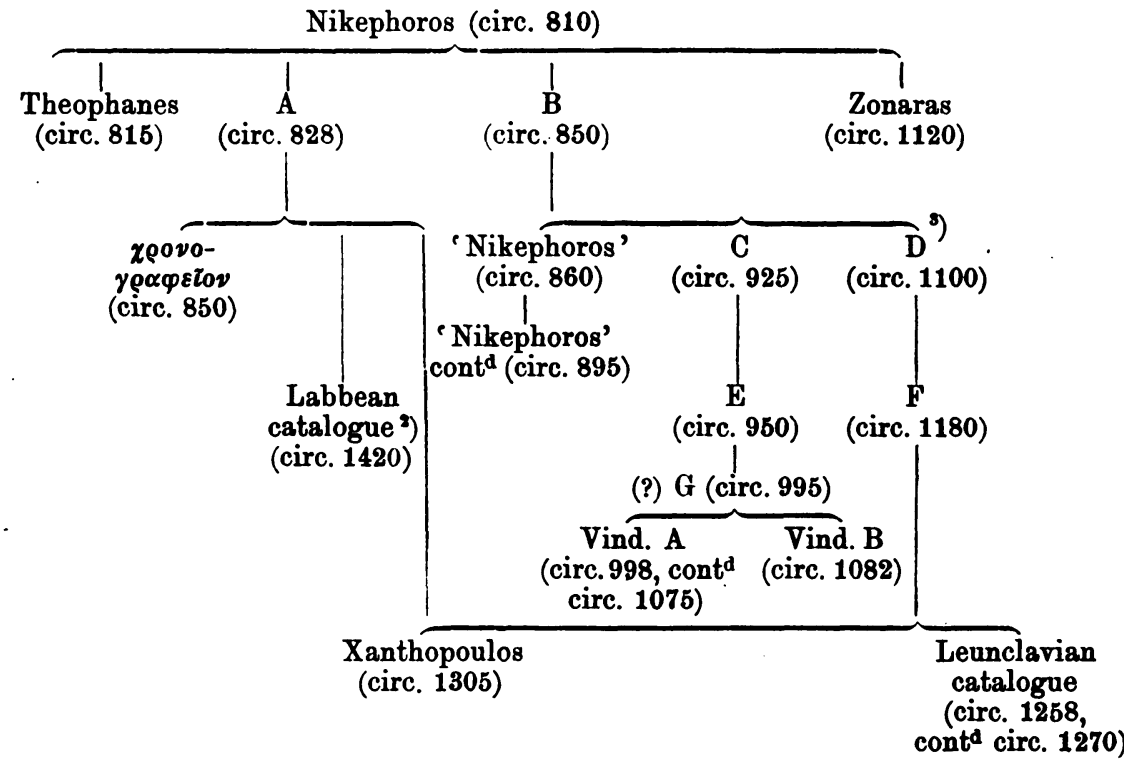

I will now tabulate the numbers of years, months, and days assigned to each patriarch by the various lists, after which it will not be difficult to restore substantially the catalogue of Nikephoros. It must be remembered however that this catalogue is itself (at least down to the accession of Kallinikos) derived from earlier lists, so that many errors may have crept into it, which our present lists, which are all derived from Nikephoros, give us no means of checking.

from this corrupt source; but its relationship to the other three lists is extremely difficult to discover. Since this list only extends to Theodotos, the composition of the original should probably be thrown back to a time immediately following the death of Nikephoros, if not before.

1) Into the sources of the later portion of the Labbean Catalogue it is not for present purposes necessary to inquire. If it be asked why Xanth. should have taken his numbers from two sources, it may be answered that the source used by Leuncl. (or copy of it) may in his time have been in places torn or obliterated.

2) The Coislinian list coincides with the Labbean down to the first expulsion of Photius (867), so that their common original may be dated about 870 .

3) There may of course have been many intermediaries between the list of 850 and that of 1100 ; and similarly in other cases. 


\begin{tabular}{|c|c|c|c|c|c|c|c|c|c|c|c|c|c|c|c|}
\hline 岁 & ๕్ష & 嘿 & 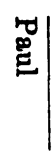 & 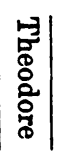 & 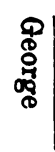 & 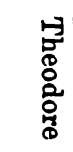 & 它兽 & 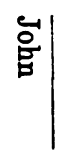 & $\begin{array}{l}\text { 胥 } \\
\text { 蜜 }\end{array}$ & 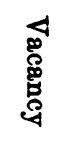 & 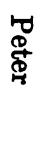 & 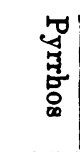 & 先 & 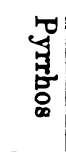 & \\
\hline 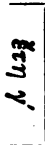 & $\begin{array}{l}\text { an } \\
n \\
n\end{array}$ & $\begin{array}{l}3 \\
3 \\
-\infty\end{array}$ & $\begin{array}{c}\tilde{3} \\
-\alpha\end{array}$ & $\left|\begin{array}{l}x \\
3 \\
z \\
x\end{array}\right|$ & $\begin{array}{l}\frac{5}{3} \\
\text { an. }\end{array}$ & $\begin{array}{l}\tilde{3} \\
\square\end{array}$ & $\begin{array}{l}m \\
3 \\
\square\end{array}$ & $\begin{array}{l}5 \\
3 \\
n\end{array}$ & $\begin{array}{l}\text { sa } \\
\text { L. }\end{array}$ & & $\begin{array}{l}\tilde{3}^{*} \\
\text { है }\end{array}$ & 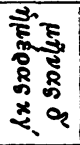 & $\begin{array}{l}\mathbb{3} \\
\mathbf{s} \\
\dot{+}\end{array}$ & $\begin{array}{l}\text { s. } \\
\text { ? }\end{array}$ & 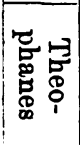 \\
\hline & 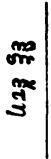 & & & & & 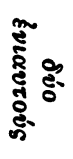 & $\begin{array}{l}\vdots \\
\vdots \\
3 \\
3\end{array}$ & & 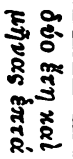 & & & 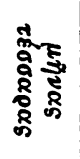 & 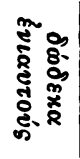 & & 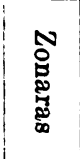 \\
\hline
\end{tabular}

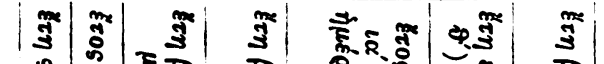

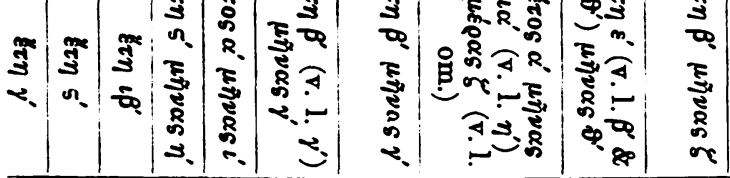

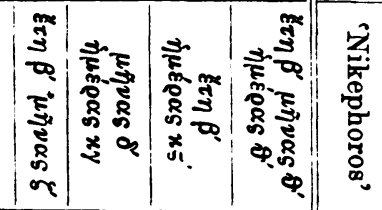

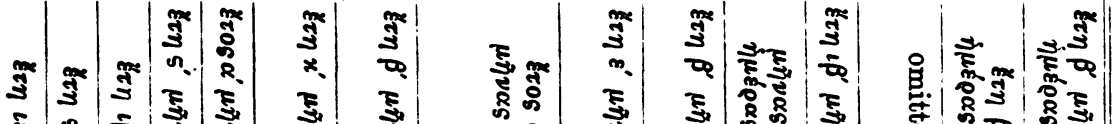

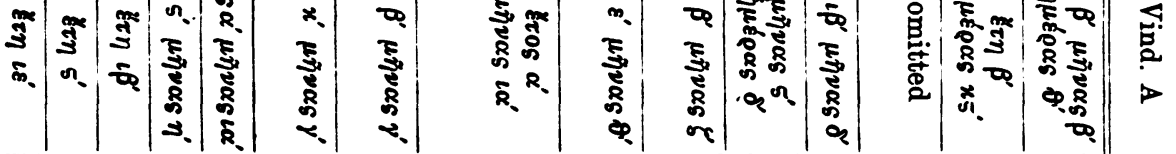

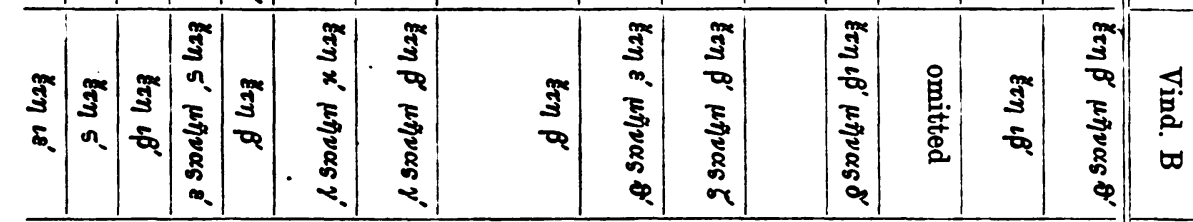

范

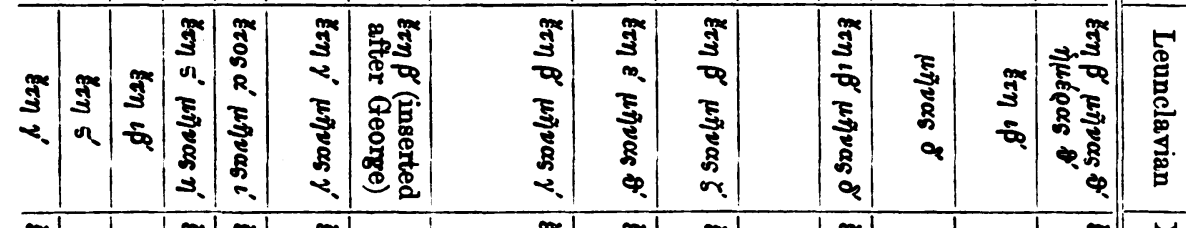

\begin{tabular}{|c|c|c|c|c|c|c|c|c|c|c|c|c|c|c|c|}
\hline$\underset{\alpha}{\infty}$ & $\begin{array}{l} \\
z \\
3 \\
n\end{array}$ & 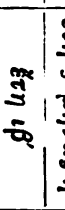 & 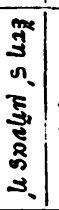 & 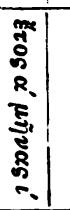 & 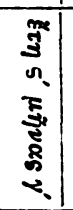 & $\begin{array}{l}3 \\
3 \\
\square\end{array}$ & 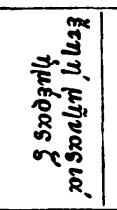 & 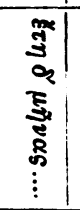 & 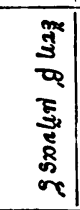 & 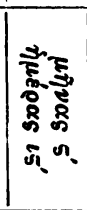 & 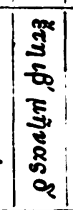 & 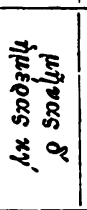 & 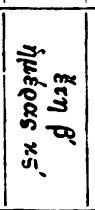 & 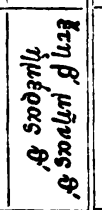 & 惫 \\
\hline & $\begin{array}{l}n \\
\text { a }\end{array}$ & $\begin{array}{c}m \\
\text { Dे } \\
\end{array}$ & $\begin{array}{l}n \\
n \\
n\end{array}$ & 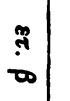 & $\begin{array}{l}m \\
\tilde{\Sigma} \\
\tilde{\Sigma}\end{array}$ & 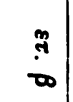 & $\begin{array}{l}n \\
\stackrel{n}{a} \\
\Rightarrow\end{array}$ & $\begin{array}{l}n \\
0\end{array}$ & $\stackrel{n}{\stackrel{n}{2}}$ & & $\begin{array}{c}m \\
5 \\
\infty\end{array}$ & 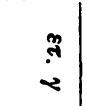 & 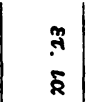 & $\begin{array}{l}n \\
\vdots \\
2\end{array}$ & \\
\hline
\end{tabular}

\begin{tabular}{|c|c|c|c|c|c|c|c|c|c|c|c|c|c|c|}
\hline 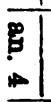 & \begin{tabular}{l|l|} 
\\
0 \\
0
\end{tabular} & $\begin{array}{ll} & \\
0 & 1\end{array}$ & \begin{tabular}{l|}
0 \\
0 \\
0 \\
0
\end{tabular} & 焉 & $\begin{array}{l}8 \\
0 \\
\infty \\
\infty\end{array}$ & $\begin{array}{l} \\
\\
\\
\end{array}$ & 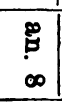 & \begin{tabular}{l}
0 \\
\hdashline \\
$*$ \\
$*$
\end{tabular} & $\begin{array}{l}0 \\
0 \\
0\end{array}$ & \begin{tabular}{l|}
0 \\
0 \\
0
\end{tabular} & 赵 & \begin{tabular}{l|l|} 
\\
\hdashline \\
\end{tabular} & $\begin{array}{l}0 \\
0 \\
0\end{array}$ & 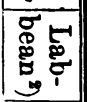 \\
\hline 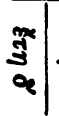 & $\begin{array}{l}5 \\
3 \\
n\end{array}$ & 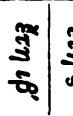 & $\begin{array}{l}3 \\
\text { ज. } \\
n\end{array}$ & 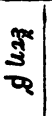 & $\mathfrak{g}^{\infty}$ & 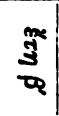 & $\begin{array}{l}m \\
\overrightarrow{3} \\
\vec{q}\end{array}$ & 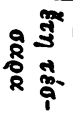 & $\begin{array}{c}\text { है } \\
\text { हैँ } \\
\text { है } \\
\text { के }\end{array}$ & 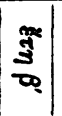 & 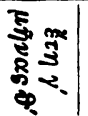 & $\begin{array}{l}m \\
3 \\
5 \\
5\end{array}$ & 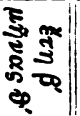 & \\
\hline
\end{tabular}


I will now proceed to consider the numbers in detail.

In the $1^{\text {st }}$ episcopate of Pyrrhos there is practical unaniminity in favour of ' 2 y. 9 m. 9 d.' The ' $\mu \tilde{\eta} \nu \alpha_{S} \beta^{\prime}$ ' of Vind. A is an accidental repetition of the number of years, and Vind. $B$ in accordance with its usual practice omits the days. The '5 years' of Lab. is obtained by adding together the 2 years of his first episcopate (months simply

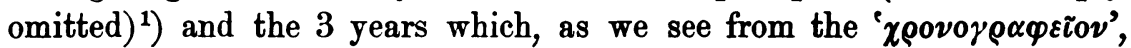
the London, and the Coislinian list, were assigned by $A^{2}$ ) to his second. Here and in the case of Theodore this catalogue omits the $2^{\text {nd }}$ episcopate and gives the sum of both under the first.

In the case of the next bishop, Paul, we have a curious variation: in the number of days there is unanimity; but, setting aside the

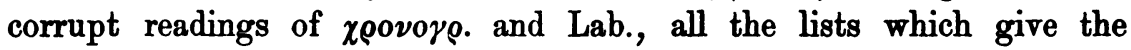
number of days give the years as ' 2 ', while the rest have ' 12 '. The omission of ' $~ \imath$ ' is however the commonest of errors, and I cannot regard its omission in these particular instances as anything more than a coincidence: the readings of Vind. B and Leuncl. show that

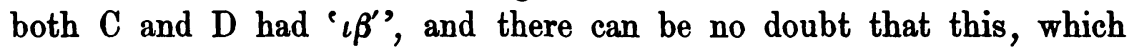
is the nearer to historical fact, is the correct reading, though, as we shall presently see, Paul's episcopate really lasted over 13 years.

In the $2^{\text {nd }}$ episcopate of Pyrrhos $A$ has ' 3 years' ${ }^{3}$ ) the rest ' $4 \mathrm{~m}$. $23 \mathrm{~d} .^{\prime 4}$ ), which is clearly the true reading.

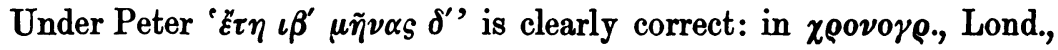
and Lab. (and therefore in A) ' $\iota$ ' has dropped, while in 'Nikephoros' the number has been displaced by that of the next patriarch, Thomas.

The length of the vacancy is stated only by Vind. A and Xanth., and unfortunately with a variation as to the days, the former having ' $\boldsymbol{d}^{\prime}$ ',

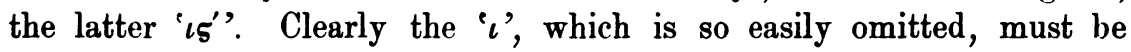
original, but between ' $\delta$ ' ' and ' $\boldsymbol{~}$ ' ' it is harder to choose; the former may have come in from the number of the months of the last patriarch, the latter from the months of the vacancy. The former alternative however seems the more probable, and the correctness of Xanth.'s ten is a presumption in favour of that of his unit: I therefore accept ' 15 '.

To the next bishop, Thomas, all except Leuncl. assign 2 y. $7 \mathrm{~m}^{5}$ ),

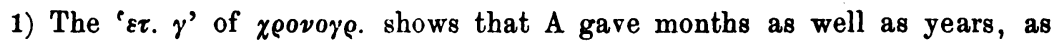
indeed they are actually found in its derivative Lond.

2) I refer to the stemma above.

3) The '9 months' of Lond. is transferred from the $1^{\text {st }}$ episcopate.

4) Zonaras omit the days.

5) The ' 2 years' of Lab. is not an exception, for this number, as in the 
while in the case of John, who follows, Theophanes and B agree in '5 y. 8 m.', while A has '4 years' (months doubtful). Here the testimony of Theophanes and the superiority of B over A decide for the former.

Passing to Constantine, the ' $\varepsilon \tau \eta \eta^{\prime}$ ' of $\mathrm{A}$ is perhaps due to repetition of the last letter of ' $z \tau \eta$ '), while the ' $2 \mathrm{y} .3 \mathrm{~m}$.' of Leuncl. is transferred from Theodore ${ }^{2}$ ), as shown by the notice of deposition, which cannot apply to Constantine. There can therefore be no hesitation in accepting ' 1 y. $11 \mathrm{~m}$. 7 d.', which Vind. B, as in the second episcopate of Theodore, rounds off into ' 2 years', while Vind. A omits the days.

To Theodore's first episcopate the lists in general assign 2 y. $3 \mathrm{~m}^{3}$ ): Leuncl. and Xanth. however omit the months, though Leuncl., as above mentioned, gives the correct number under Constantine ${ }^{4}$ ); Lab., as in the case of Pyrrhos, gives the sum of the two terms.

Under the next patriarch the lists present a strange variation. As to the months all agree, but as to the years there are no less than 5 readings: Theoph. and Xanth. give '6', the shorter 'Nikephoros' '2',

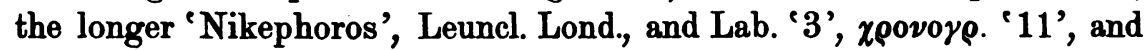
Vind. '20'. The reading of the shorter 'Nikeph.' is clearly a transference from Theodore, and that of the longer 'Nikeph.' a transference from the months ${ }^{5}$ ), while, as against the readings of Vind. and xpovoro., the agreement of Theoph. and Xanth., as well as the historical facts, are decisive for ' 6 '. Xanth. Lond., and Coisl. append the statement that George was deposed, while Vind. B expressly states

$1^{\text {st }}$ episcopate of Pyrrhos, is obtained by simply omitting the months. Here again the divergence from xpov. shows that in $\mathbf{A}$ the months were stated. In Lond. the years are accidentally omitted.

1) The original reading would of course be ' $\varepsilon_{\tau}$ 's', but a careless transcriber might through force of habit write ' $z \tau \eta$ ' and repeat his own ' $\eta$ '.

2) So perhaps the '2 years' of Lond., since A seems to have had ' $z_{\tau} \eta$ ' $\eta$ '.

3) The Menology of Basil also assigns 2 y. $3 \mathrm{~m}$. to Theodore.

4) The omission of the months by Xanth. as well as Leuncl. makes it probable that the transference of Theodore's term to Constantine was already made in $F$.

5) I cannot agree with de Boor that the longer recension 'of 'Nikeph.' was made at Jerusalem, or that it is necessarily the later of the two: here the fact that its reading agrees with Leuncl. goes to show that it is the earlier one and that it was in fact that of $B$ : this would also explain the reading of Vind., ' $x$ '' being an easy corruption of ' $y$ ', but not of ' 5 ''. The fact that the list of patriarchs is preceded by one of high-priests is surely a sufficient explanation of the priority of Jerusalem. Moreover, if this recension had been made at Jerusalem, we should have expected the list of patriarchs of Jerusalem to be continued to the author's time. 
that he died. It is not however the habit of the catalogue to record the fact of a patriarch's death, and this notice is therefore probably only a tag intended to lead up to the restoration of Theodore ${ }^{1}$ ): all therefore that can be deduced from it is that the statement of deposition was not found in G (or E). The statement, which is probably that of A, may be a mere transference from Theodore; but the different form of the statement, as found in Xanth. ${ }^{2}$ ), is somewhat against this, and the silence of the other lists is considerably discounted by the facts that 'Nikeph.' and Vind. A do not mention the undoubted deposition of Theodore, and that Leuncl. is at this point so confused that little confidence can be placed in its testimony. ${ }^{9}$ ) It is therefore highly probable that the addition of $A$ is original.

To Theodore's second episcopate 'Nikeph.' and F agree in assigning

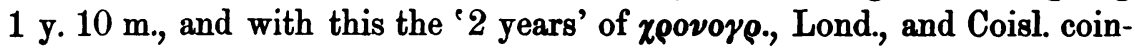
cide: on the other hand Vind. A has ' 1 y. 11 m.'; and, as Vind. B rounds it off to ' 2 years', it is probable that this was the reading of G. Theoph. differs from all the others in giving ' 3 years'. Here the agreement of $\mathrm{A}$ and $\mathrm{B}$ must counterbalance the authority of Theoph., and the agreement of 'Nikeph.' and F must decide in favour of ' 1 y. 10 m.' as against the reading of Vind.

Under Paul there is a general consensus in favour of '6 y. 8 m.', Vind. B alone having ' $\mu \tilde{\eta} \nu \alpha S{ }_{S}$ ' and Lab. ' 2 years'.")

As to the remaining three names, there is but little divergence: to Kallinikos all except Lab., which has made the ordinary error of dropping the ' $\iota$ ', assign 12 years; to Cyrus all without exception assign 6 years; under John the ' 15 years' of Vind. are clearly transferred from Germanus and the ' John ${ }^{5}$ ), while the ' 4 years' of Lab. and Lond. tends to show that

1) Ephraim in his iambic version of the catalogue also states that George died; but, as he adds this notice to every bishop whom he did not know to have abdicated or been deposed, his statement shows no more than that of Vind. B, i. e. that the deposition was not recorded in the copy of the catalogue which he used.

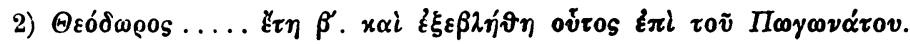

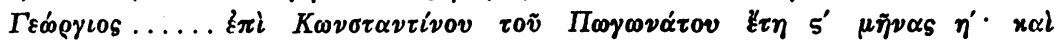

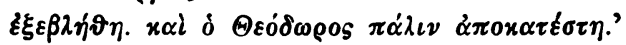

3) As already noticed, it transfers the term and deposition of Theodore to Constantine, and it places Theodore's two episcopates together after George.

4) Transferred either from the Theodore's second term or from the term assigned by Lab. to Kallinikos.

5) The blank left for the number of months in both cases shows this clearly. As already noticed, months are not found in any of the lists between Paul and Niketas, so that the reading can hardly be in place here. 
this transference had already been made in some copy of A which was used by these three compilers. All others give ' 3 years'. The Vienna lists alone add the statement that John was deposed; but, as this statement is supported by Ephraim and Zonaras, it was perhaps contained in the original catalogue of Nikephoros. This catalogue may then be substantially restored as follows.

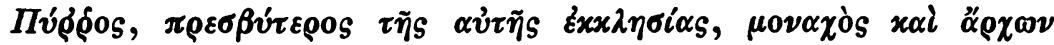

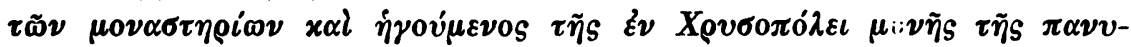

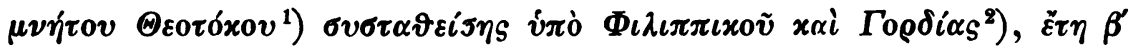

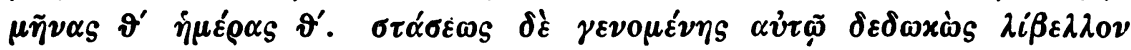
$\pi \alpha \rho \eta \tau \eta \dot{\gamma} \sigma \alpha \tau$.

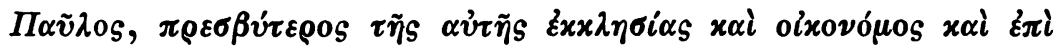

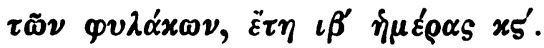

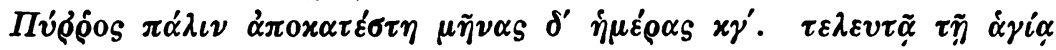
$\Pi \varepsilon v \tau \eta \eta \propto \sigma \tau \tilde{\eta}$.

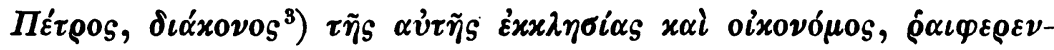

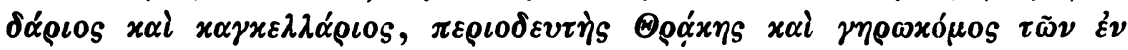

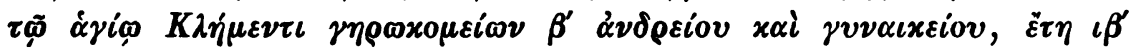
$\mu \tilde{\eta} \nu \alpha S \delta^{\prime}$.

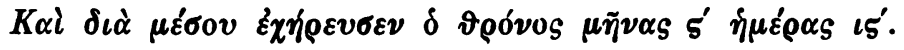

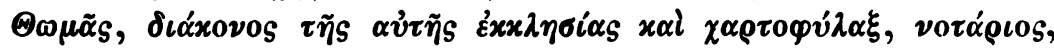

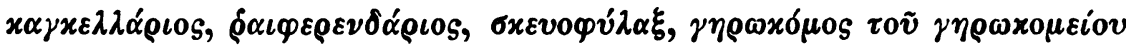

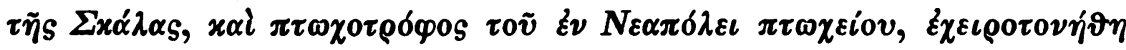

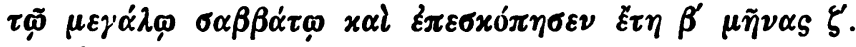

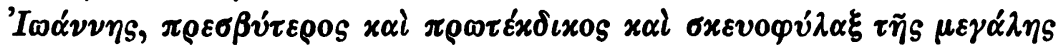

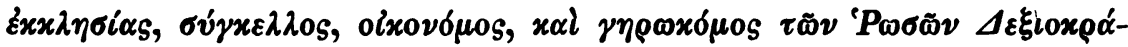

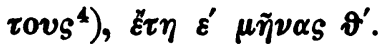

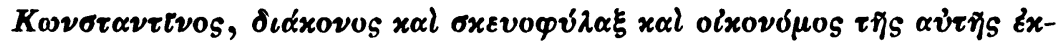

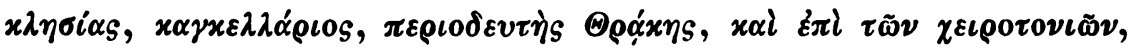

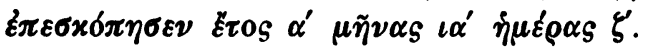

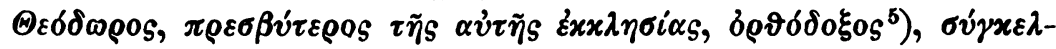

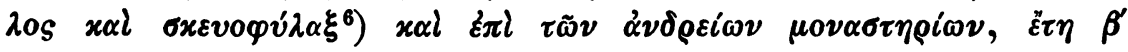

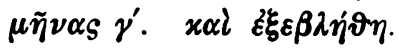

1) $\tau \tilde{\eta} s \pi \alpha v$. $\Theta \varepsilon o \tau$. is only in Xanth., but is supported by Ephraim.

2) The mention of Gordia is only in Xanth., but it cannot be an interpolation.

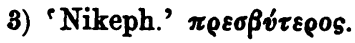

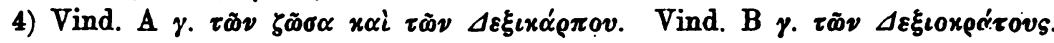
I follow Fischer in correcting from Ephraim's iambic version of the catalogue.

5) This word is only in 'Nik.', but I cannot see how it can have been interpolated, while it would naturally be omitted as out of place.

6) Xanth. adds ' $x \alpha \gamma x \varepsilon \lambda \lambda \alpha$ '́p 


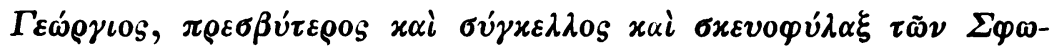

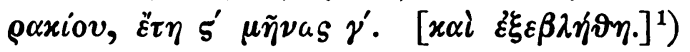

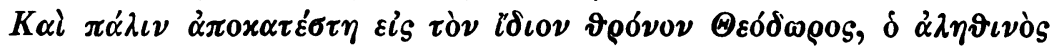

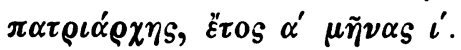

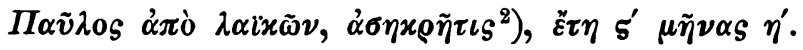

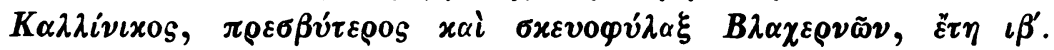

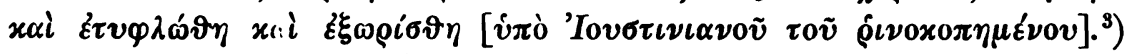

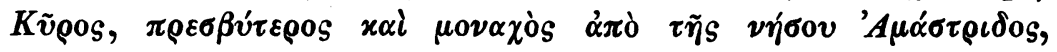

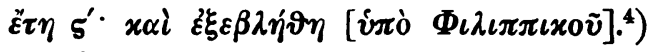

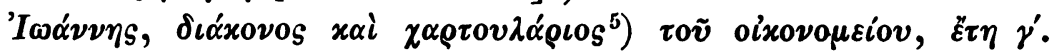
$\left.\left[\begin{array}{lll}x \alpha i & \dot{\varepsilon} \xi \varepsilon \beta \lambda \dot{\eta} \vartheta \eta]^{6}\end{array}\right]^{6}\right)$

I will now proceed upon these data to consider the actual chronology of the patriarchs.

The patriarch Sergius was ordained on Apr. 18, 610 7 ) and held the see according to the catalogues $28 \mathrm{y} .7 \mathrm{~m} .21 \mathrm{~d}$. This gives us Dec. 9, 638 for the date of his death, which agrees well enough with the statement of Constantine Porphyrogennetos that he was buried on Sun. Dec. 13 in that year. ${ }^{8}$ ) His successor, Pyrrhos, as we know from Nikephoros, abandoned his see shortly after the elevation of Constantine IV, which was at the time of the vintage (begins about the middle of September) 641, and his successor, Paul, was ordained in October. From the way in which this last statement (which is also found in Theophanes) is introduced by Nikephoros I should gather that the preceding events were not in October, and that therefore the flight of Pyrrhos was in the latter half of September. Now, as the custom of ordaining on Sundays or great festivals was by this time well established, the earliest possible date for Pyrrhos' ordination is Dec. 13, 638: but it is not likely that he was ordained on the day of his predecessor's funeral; and, as any later date than Dec. 20 would carry his

1) Xanth., Coisl., Lond.

2) $\mathrm{F} \pi \rho \omega \tau \sigma \alpha \sigma \eta x \rho \eta \tilde{\imath} \iota$.

3) Inserted by 'Nik.' only.

4) 'Nik.' ijò $\Phi \iota \lambda i \pi \pi 0 v$. Xanth. $\pi \alpha \rho \dot{\alpha} \Phi\llcorner\lambda \iota \pi \pi \iota x o \tilde{v}$; cet. om.

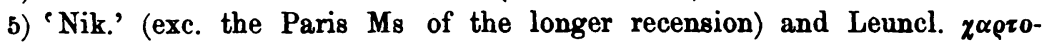
$\varphi v i \alpha \xi$ (a correction to a more usual word).

6) Vind., Ephr., cf. Zonaras.

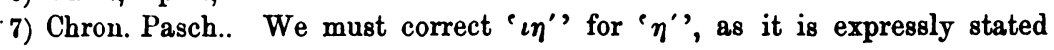
that the day was Easter Eve (see Cuper in Boll. Act. SS. Aug. tom. 1 p. 77).

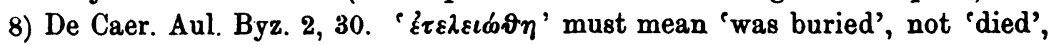
since he adds that the two preceding patriarchs, Cyriac and Thomss, were 'perfected' on a Sunday, whereas we know from the Paschal Chronicle that it was their funerals, not their deaths, which were on that day. 
episcopate into October, we may fix his ordination to that day and his flight after an episcopate of 2 y. $9 \mathrm{~m} .9 \mathrm{~d}$. to Sept. 29, 641 .

His successor, Paul, was, as we have seen, ordained in October 641, and the Catalogue gives him 12 y. $26 \mathrm{~d}$. We know however from the 'Narratio in S. Martinum' that he died between Dec. 20 and Dec. 27, 654 ${ }^{1}$ ), and, according to the most natural interpretation, on Dec. 27. We have therefore an instance in which the Catalogue is in error. The '26 days' we may accept; but the absence of months cannot be correct, since this would bring his ordination to the end of November. 'One month' is possible, but this would give a long interval between Pyrrhos' flight and the ordination of his successor, and, in order to make the ordination fall on a Sunday, it would be necessary to make Paul's death fall on Christmas Day, though, if this had been the case, we can scarcely doubt that, like the death of Pyrrhos on Whit Sunday, it would have been stated in the Catalogue. We must therefore accept 'two months' and fix his death to Dec. 27, 654 and his ordination to Oct. 1, 641, which was in fact a Sunday. ${ }^{2}$ ) The origin of the reading of the Catalogue is now clear: the original entry was ' $\tilde{\varepsilon} \tau \eta \iota \gamma^{\prime} \mu \tilde{\eta} \nu \alpha S \beta$ '

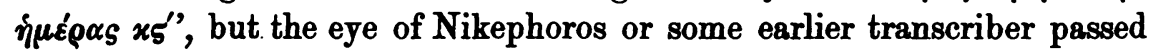

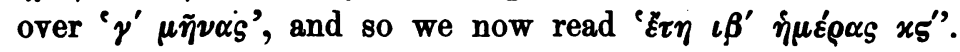

In the $2^{\text {nd }}$ episcopate of Pyrrhos also the term assigned by the Catalogue cannot be correct. Whit Sunday 655 fell on May 17; and therefore, if his episcopate lasted $4 \mathrm{~m}$. $23 \mathrm{~d}$., his restoration will fall on Dec. 24, 654; but, even if Paul's death could be placed earlier than Dec. 27, it is quite certain from the 'Narratio' that Pyrrhos had not been restored on that day. The earliest day on which his restoration can reasonably be placed is Sun. Jan. 4, 655 ${ }^{3}$ ), which leaves $4 \mathrm{~m} .13 \mathrm{~d}$. for his tenure of the see. We may then fairly assume that the original

1) In the Zeitschr. für kathol. Theologie 1892 p. $375 \mathrm{ff}$. E. Michael brings strong arguments for placing Martin's arival, and therefore Paul's death in 653; and, if we might accept this, many difficulties would be solved. He does not however notice that the $9^{\text {rd }}$ day after Sept. 17 is said to have been a Friday, which agrees only with 654. Andreev, who takes the same view, calculates wrongly, making the 98 ${ }^{\text {rd }}$ day fall on Dec. 20 instead of Dec. 19.

2) The shortness of the interval is natural, when we consider the tumultuary nature of the proceedings.

3) In such cases ordination was of course not required, and from the case of Eutychius it does not appear that there was any enthronisation. Eutychius seems to have reckoned his term from the day on which he first officiated as patriarch after his return, which in his case was a Sunday; and it is natural that a Sunday should be chosen for the purpose. I therefore assume that it was so in Pyrrhos' case also. 
entry was ' $\mu \tilde{\eta} \nu \alpha_{S} \delta^{\prime} \dot{\eta} \mu \varepsilon^{\prime} \rho \alpha_{S} ~ \iota \gamma$ ', and that ' $x$ ' has been substituted for ' $\iota$ ' through the eye passing to the ' $\eta \mu \varepsilon^{\rho} \alpha s{ }^{\prime}{ }^{\prime}$ ' of his predecessor.

His successor, Peter, must then have been ordained at the end of May or beginning of June; and as $12 \mathrm{y} .4 \mathrm{~m}$. are assigned to him, his death will fall in September or October 667. On the other hand Tarasius stated in the $7^{\text {th }}$ Synod that not more than 15 years elapsed between the death of Peter and the assembling of the $6^{\text {th }}$ Synod (Nov. 7, 680 ${ }^{1}$ ), clearly implying that the interval exceeded 14 years. The authority of Tarasius alone would not be of much weight; but, if we consider the dates of the succeeding patriarchs up to the accession of Theodore in the light of the following investigation, we shall see that a year must be cut off one of them in order to bring Theodore's ordination before Aug. 13, 678, and that of his successor, George, before Sept. 10,680, at which dates they are respectively shown to have been in office by the letters of the Emperor prefixed to the Acts of the $6^{\text {th }}$ Synod. ${ }^{2}$ ) Now the date of Constantine's ordination is, as we shall see, fixed by the concurrence of the day obtained with a Sunday: hence we have to choose between Peter, Thomas, and John, and the statement of Tarasius must decide for Peter; especially as it is only in his case that a simple explanation of the error can be given: the reading ' $\varepsilon$ c $\tau \eta \iota \beta^{\prime}$ ' has come in from the term assigned to Paul ${ }^{3}$ ), who also succeeded Pyrrhos, and whose name also consists of 6 letters, begins with ' $\Pi$ ', and ends with 'os'. I therefore assume that the original entry was ' $\varepsilon \tau \eta \iota \alpha$ ' $\mu \tilde{\eta} \nu \alpha S \delta^{\prime}$ ' and fix his death to 666. His successor, Thomas, was ordained on Easter Eve, which in 667 fell on Apr. 17, after a vacancy of $6 \mathrm{~m} .16 \mathrm{~d}$.: Peter's death was therefore on Oct. 1. The long interval was no doubt due to the Emperor's absence in the West.

To Thomas our Catalogue assigns 2 y. $7 \mathrm{~m}$., which brings his death to Nov. 669; and, as his celebration is recorded in the Menology of Constantinople under Nov. $15^{4}$ ), we may fix it to that day. A slight difficulty here arises, since in the $6^{\text {th }}$ Synod George the chartophylax spoke

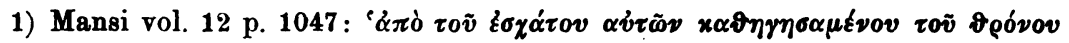

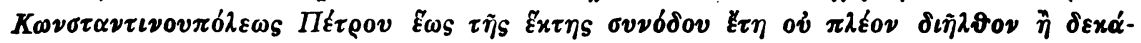

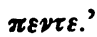

2) Mansi 11 p. $195 \mathrm{ff}$.

3) Since, as we have seen, the reading is wrong in Paul's case also, it follows that the error is there older than Nikephoros.

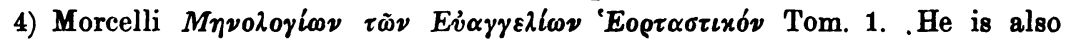
recorded with other patriarchs under Nov. 20 (Cuper Boll. Act. SS. Aug. tom. 1 p. 83); but the day on which he is commemorated alone is clearly the correct one. 
of his episcopate as one of two years ${ }^{1}$ ), though, as it in fact exceeded $2 \frac{1}{2}$ years, it should have been described in round numbers as ' 3 years'. The excess is however only 29 days; and, as George wished to excuse him for not communicating with the Pope, it was to his interest to make the episcopate appear as short as possible. The statement that during the whole of his episcopate the Saracen blockade prevented him from entering into communication with Rome is of course not true: the receipt of the news of the Emperor's death and the expedition of his successor to Sicily in the latter half of 668 is proof to the contrary. At the same time George's statement may be taken as proof that the attacks upon Constantinople began, as we should gather from Nikephoros, in the spring of 669, not, as Theophanes would have us believe, in 673 .

The ordination of John may then be placed at the end of November or beginning of December 669. Accordingly the 5 y. $9 \mathrm{~m}$. assigned to him bring us to Aug. 675; but the confusion between the many patriarchs of the name in the Menologies makes it very difficult to fix the day. Setting aside John Cbrysostom and John the Faster, as to whose days there is no doubt, the name of John, patriarch of Constantinople, occurs under Feb. $21^{2}$ ), Aug. $18^{3}$ ), Aug. 254), Aug. $26^{5}$ ), Aug. $30^{6}$ ), and Aug. $31^{7}$ ). Now the patriarch celebrated on Aug. 30 or 31 (a transference of one day is a frequent occurrence) is undoubtedly John the Scholastic, whose death is fixed by Theophanes to Aug. $31^{8}$ ); while the patriarch celebrated on Feb. 21, though called John the Scholastic, can hardly be other than John the Cappadocian, who died about that time. ${ }^{9}$ ) Since therefore the Monothelete of $712-715$ and the Iconoclast of $836-842$ would scarcely be celebrated, and later patriarchs of the name are excluded by the dates of the Menologies in which the names occur, it would seem that for our John we have to choose between Aug. 18, Aug. 25, and Aug. 26. Of these Aug. 25 rests upon the best authority; but, as in all three cases he is joined with other patriarchs ${ }^{10}$ ), it is doubtful whether any was the

1) Mansi 11 p. 576.

2) Menologies quoted by Sergy (полный мвсядесловъ востока vol. 1 pt. 1 p. 46).

3) Men. Clarom. (Sergy vol. 2 pt. 1 p. 216).

4) Men. Basil.

5) Men. Paris. (Sergy vol. 1 pt. 1 p. 84).

6) Men. S. Sab. and others (Cuper Boll Act. SS. Aug. tom. 1 p. 102).

7) Men. Const. (Morcelli vol. 1).

8) Theoph. AM 6069.

9) He wrote to the Pope on Jan. 19, and his successor was ordained on Feb. 25 (Theoph. AM 6012).

10) Of the other three patriarchs celebrated on Aug. 25 (or 26) Epiphanius died on 
actual day of his death, and we can only accept the testimony of the Menologies as some confirmation of the previous conclusion that he died in August, which date is further confirmed by that of the ordination of his successor.

Constantine held office 1. y. 11. m. 7 d., and his celebration is recorded in the Menology of Basil under Aug. 9. ${ }^{1}$ ) This enables us to fix his death to Aug. 9,677 and his ordination to Sept. 2, 675, which was in fact a Sunday. The ordination of Theodore will then fall at the end of August or beginning of September, and his deposition after an episcopate of $2 . \mathrm{y} .3 \mathrm{~m}$. in November or early in December 679; to the same last two months of 679 we may fix the ordination of George. Much confusion has been introduced into the patriarchal chronology by the statement of Theophanes that the $6^{\text {th }}$ Synod was in the $3^{\text {rd }}$ year of George ${ }^{2}$ ), from which Le Quien, Cuper, and other inquirers have thought it necessary to fix George's accession not later than Nov. 7, 678. It is however clear that this assertion is not derived from any independent authority (events were not dated by the years of bishops), but only from Theophanes' own synchronisms, in which the year of

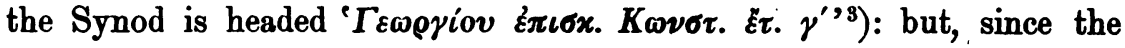
synchronisms of Theophanes are valueless, any statement that is founded on them is valueless also.

Since George held the see 6 y. $3 \mathrm{~m}$., his episcopate must have ended in the first three months of 686 . Here a slight difficulty arises, since his celebration is recorded in the Menology of St. Sabas under Apr. 6, and in other Menologies under Aug. 18. ${ }^{4}$ ) Now it is clear

June 5, and Gennadius probably on Nov. 17, where his celebration is also recorded: only Menas actually died in August. As to the date of the death of Alexander, who is celebrated on Aug. 30, nothing is known; upon George, who is celebrated on Aug. 18, and Paul, who is celebrated on Aug. 30 (or 31), I shall have more to say later.

1) The later Menologies give Jul. 29, but the Basilian Menology is a much better authority. It is also possible that the patriarch celebrated on Jul. 29 was Constantine II, since some Menologies record a Constantine 'ó víos' under Jul. 30 (Cuper Boll. Act. SS. Aug. tom. 1 p. 100). An Iconoclast who died during the triumph of his opinion might possibly be celebrated, as was in fact the case with Anastasius.

2) Theoph. A M 6177.

3) A similar instance is found under A M 6207, where the translation of Germanus is assigned to the $2^{\text {nd }}$ year of Anastasius, though it is certain that it was in the $3^{\text {rd }}$.

4) Sergy vol. 2 pt. 1, p. 216. Our George must be meant in both instances, since the only other patriarch of the name lived in the 12th century and is therefore excluded by the dates of the Menologies concerned. I take the reference to

Byzant. \%eitschrift VI 1. 
that both cannot be right; and, as Aug. 18 is also the date of the celebration of John, we should probably decide for Apr. 6. ${ }^{1}$ ) If however we suppose his episcopate to have been terminated by death, we have a discrepancy; for, though it would be easy by supposing a somewhat longer vacancy than usual to make his episcopate extend to Apr. 6, this date, as we shall see, does not accord with that assigned to the celebration of his successor. If on the other hand we accept the statement of $A$ that he was deposed (see above p. 43), all diffculty vanishes. A cause for this deposition is not far to seek: his deposed predecessor would naturally seek restoration by all means in his power; and for this the accession of a new Emperor in Sept. 685 would afford a welcome opportunity. If the fact of his deposition be accepted, the date here assigned to the termination of his episcopate is strongly supported against the more usually received dates 683 or $684^{2}$ ); for both these dates fall before the death of Constantine, who would not be likely to undo his own work.

Theodore's second episcopate lasted $1 \mathrm{y} .10 \mathrm{~m}$., and the Menology of Constantinople and that of Basil record his celebration under Dec. 28: hence we may fix his record death to Dec. 28,687 , his restoration to the latter half of February or beginning of March 686, and the death or deposition of George. to February or the first few days in March in that year.

The earliest date for the ordination of Paul will then be Jan. 5, 688, and the $5 \mathrm{y} .8 \mathrm{~m}$. of his patriarchate brings us to the end of August or beginning of September 694. The Menologies record a Paul, patriarch of Constantinople, under Aug. 20, Aug. $30^{3}$ ) (or 31) $)^{4}$, and Sept. $2^{5}$ ), whom they qualify as ' $\delta$ véo'. Now the celebration of Paul the Athanasian confessor is clearly fixed, and the Monothelete of 641-654 died, as we have seen, on Dec. 27: hence our Paul and Paul the Cyprian alone remain. As to the latter, Theophanes tells us that he abdicated

the Menology of S. Sabas from Cuper (Boll. Act. SS. Aug. tom. 1 p. 85), having been unable to obtain access to the printed text of that work.

1) It is not impossible that the date Apr. 6 has arisen from confusion with George of Mytilene, a confessor of Iconoclast times, who is celebrated on Apr. 6 or 7.

2) These dates are derived from the statement of Theophanes that he held office 3 years after the Synod, a number which is obtained by deducting the supposed year of his episcopate at the time of the Synod from the total term of 6 years which is assigned to him.

3) Sergy vol. 2 pt. 1, p. 219.

4) Men. Paris (Sergy 1. 1. 98); Men. Constant.

5) Men. Constant. 
through illness on Aug. 31 and died shortly afterwards. ${ }^{1}$ ) Now in the appendix to the Menology of 1843 it is stated that the celebration of Paul ' $\delta$ véos' was originally on Sept. 2, but had been transferred to Aug. $30^{2}$ ), while the Menology of Constantinople records John \& Paul $\delta$ ע ́́os under both Aug. 31 or Sept. 2. There can therefore be little doubt that the patriarch celebrated on Aug. 30 (or 31) or Sept. 2 is Paul the Cyprian $^{3}$ ): hence, if the Paul who is celebrated on Aug. 20 is not the same, he must be our Paul, since no other remains. The space from Jan. 5 to Aug. 20 is indeed nearer 7 months than 8; so that, if the Catalogue is correct, we must suppose that he in fact died a day or two later than Aug. 20.

At this point the detailed portion of the Catalogue ceases. For the remaining three patriarchs we have years only; and I have already shown from the case of Germanus (p. 37) that these years are probably not round numbers but the result of a deduction of the number of the year of ordination from that of the year of death or deposition. Now we know from Theophanes that the translation of Germanus was on Aug. 11, 715; hence, as 21 years are assigned to the three preceding patriarchs, the ordination of Kallinikos must have fallen in the indictional year which ends Aug. 31, 694, and we must therefore place it on Sun. Aug. 30. 12 years are assigned to Kallinikos, 6 to Cyrus, and 3 to John; the accession of Cyrus therefore falls in the indictional year Sept. 1,705 - Aug. 31, 706, and the accession of John in the indictional year Sept. 1, 711 - Aug. 31, 712: but, since in both cases the vacancy was due to deposition, and the Menologies therefore give no help, there is little to aid us in fixing the time of year at which the ordinations took place.

Kallinikos was, we know, deprived by Justinian shortly after his recovery of the Empire: therefore, in order to fix the date of his deprivation, we must first fix that of Justinian's restoration. Theophanes relates the recovery of the city by Justinian under the year 705/6, and the recovery of the Empire with the capture and death of Tiberius and the deposition of Kallinikos under the year 706/7. Theophanes was hewever compelled by the form of his work to arrange every

1) Theoph. AM 6276. The 1st Vienna list would place his abdication on 4n. 19

2) 2) Perhaps because Alexander was celebrated on that day.

$\therefore$ 3) In the Leunclarian Catalogue Paul the Cyprian is styled ' $\delta$ véos'. If r.celli is right in assigning the Menology of Constantinopie to the reign of Constanine Kopronymos, this identification of course falls to the ground; but Bergy hus shown good reason or relegating it to the $9^{\text {th }}$ century. 
event under some year, whether he found any date in his authority or not, so that his testimony is in such a case of little account. Justinian's recovery of Constantinople is generally, though without any substantial ground, placed in Sept. 705. There exist however two coins of his $20^{\text {th }}$ year with the mint-mark of Constantinople ${ }^{1}$ ), which tends to show that he was in possession of the city by the end of August of that year at the latest ${ }^{y}$ ); indeed, as Theophanes tells us that he was associated in the Empire by his father ${ }^{3}$ ), the end of his $20^{\text {th }}$ year, and therefore his recovery of the city, must in all probability, be thrown back to a yet earlier period. ${ }^{4}$ ) The terms assigned to the Emperors also point to the same result. Philippikos was deposed on June $3,713^{5}$ ), and Theophanes gives him 2 y. 9 m. ${ }^{6}$ ), for which it is generally admitted that ' 1 y. 9 m.' must be substituted.7) Bede on the other hand gives him 1 y. $6 \mathrm{~m}$. These two terms may be reconciled if we suppose that Theophanes' term is a round number, covering anything between 1 y. $7 \frac{1}{2} \mathrm{~m}$. and 1 y. $101 / 2 \mathrm{~m}$., and Bede's a round number covering anything between $1 \mathrm{y} .3 \mathrm{~m}$. and $1 \mathrm{y} .9 \mathrm{~m}$. The accession of Philippikos will then be in Sept. or Oct. 711; and, as Justinian's death can scarcely have been before November ${ }^{8}$ ), we may probably place it about the middle of October. To Justinian's second reign Theophanes, Bede, and the Catalogues in general assign six years; Nikephoros however tells us that he had completed his $6^{\text {th }}$ year, and the 'xoovoreapetov', which in its list of Emperors appears trustworthy, gives him 6 y. $6 \mathrm{~m}$. As other numbers of months than six are not generally mentioned in this catalogue, we may take it as a round number and gather from it that he reigned at least 6 y. $3 \mathrm{~m}$. Hence his restoration was not later than July 705. The operations against Tiberius and

1) Sabatier, Monnaies Byzantines rol. 2 p. 35. As his son is joined with him, they must have been struck after the latter's coronation.

2) Constantine died 'initio mensis Septembris' according to the Liber Pontificalis, and the Menology of 1843 records his celebration under Sept. 2.

3) Theoph. AM 6173.

4) The association cannot have been as early as 682, where Theoph. places it. The epitaph of Ceadwalla (Bede H.E. 5, 8) proves that it was later than Apr. 20, 685.

b) Ep. Agath. Diac. (Mansi 12, p. 193): so Theoph. and Nikeph.

6) Theoph. A M. 6207.

7) 'debrepor tros... ocóyovios' Nikeph. Agathon assigns him 2 years, and so the Catalogues. Theoph. has transferred a year from Anastasius to Philippikos.

8) The news reached Rome 3 months after Oct. 24, therefore at the earliest in the $2^{\text {nd }}$ week in January (Lib. Pont. vit. Constantini). This fact prevents us from accepting $1 \mathrm{y} \cdot 9 \mathrm{~m}$. as the actual term of Philippikos' reign. The only other numbers of months mentioned by Theoph. in this passage are ' 3 ' and '6', which points to the use of round numbers. 
Herakleios may have occupied a month or two; but we cannot doubt that, as soon as he had time to devote to anything beyond his own safety, he would hasten to wreak his revenge upon the patriarch. I would therefore place his deposition at the earliest date consistent with the preceding investigation, that is in Sept. 705.

The deposition of Cyrus is related by Theophanes under the year $712 / 3$, apparently as something already completed $\left.{ }^{1}\right)$; hence we may infer that he meant to place it in the year $711 / 2$, so that his statement that Cyrus was deposed in his $6^{\text {th }}$ year ${ }^{2}$ ) is merely drawn from his own

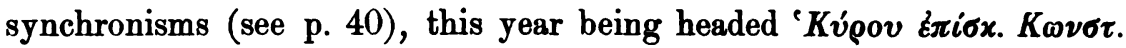
$\check{\varepsilon} \tau . \varsigma^{\prime}$, and need not prevent us from supposing that Cyrus completed his $6^{\text {th }}$ year. Now Philippikos obtained possession of Constantinople, as we have seen, in Oct. 711. Agathon tells us that even before his entry into the city he had ordered the picture of the $6^{\text {th }}$ Synod to be overthrown; and the report of his heretical tendencies reached Rome at the same time as the news of his accession and Justinian's death. It would be hard to believe that, until secured by this last event, he found time for such active interference in ecclesiastical affairs as is implied by the deposition of a patriarch; but that the change was made as soon as political affairs admitted we can scarcely doubt. We may therefore place the deposition of Cyrus at the beginning of 712, if not in Dec. 711.

Since Germanus was translated to Constantinople on Aug. 11, 715, John's episcopate must be presumed to have terminated at the end of July or beginning of August in that year. As to the manner in which it was terminated, I can scarcely doubt that the Catalogue asserted his deposition $^{3}$ ), while as against the 'obiter dictum' of Theophanes, which implies that he $\operatorname{died}^{4}$ ), I must decide for the Catalogue. ${ }^{5}$ )

The complete list of patriarchs from 638 to 715 may then be arranged as follows:

Pyrrhos

Paul

$$
\begin{aligned}
& \text { Dec. } 20,638 \text { - Sept. } 29641 . \\
& \text { Oct. 1, } 641 \text { - Dec. 27, } 654 \text {. }
\end{aligned}
$$

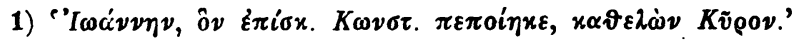

2) Theoph. A M 6177.

3) Since neither the London nor the Coislinian list states his deposition, this now appears much less certain.

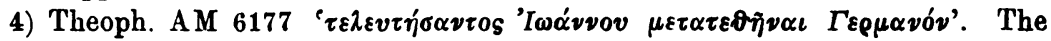
first two words seem to be a mere introductory formula, leading up to the translation of German's, and do not necessarily rest upon any authority. The passage is not in the main narrative but in the marginal note in the Trullan Synod.

5) It is of course possible that the statement of the Catalogue is accidentally repeated from Cyrus. 
54 I. Abteil. E. W. Brooks: On the lists of the patriarchs of Const. from 638 to 715

Pyrrhos (restored) Jan. 4, 655 - May 17, 655.

Peter

May/June 655 - Oct. 1, 666.

Thomas

John

Apr. 17, 667 - Nov. 15, 669.

Constantine

Nov./Dec. 669 - Aug. 675.

Theodore

Sept. 2, 675 - Aug. 9, 677.

George

Aug./Sept. 677 - Nov./Dec. 679.

Theodore (restored)

Paul

Kallinikos

Jan. (5?), 688 - Aug. (21 ?), 694.

Cyrus

Aug. 30, 694 - Sept. (?), 705.

John

Germanus

Sept. (?), 705 - Jan. 712 (?).

Jan. 712 (?) - Jul./Aug. 715.

Aug. 11, 715.

London.

E. W. Brooks. 